\title{
Do educators in initial training have stereotypes about adult education?
}

\author{
Pilar Moreno-Crespo ${ }^{1 a}$, and Olga Moreno-Fernández ${ }^{2}$ \\ ${ }^{1}$ University of Huelva, Faculty of Educational Sciences, March 3 Avenue, 21071 Huelva, Spain \\ ${ }^{2}$ University of Seville, Pyrotechnic St.., 41013 Sevilla, Spain
}

\begin{abstract}
The initial training that future educators receive must be prepared for the education of adults, which includes knowing the characteristics of the group and overcoming the stereotypes towards them. However, not always achieved. The purpose of this communication is to approximate the stereotypes that early educators (elementary school teachers and social educators) have about adult education. To this end, 110 students of teachers in the specialty of Primary Education and 151 of social education responded to a Likert scale questionnaire in which eight items related to stereotypes towards adult education. From the results obtained, the most outstanding stereotypes are present in issues related to the management of new technologies and the learning capacity of this group.
\end{abstract}

Keywords: Initial training; stereotypes; adult education

\section{Introduction}

In the last decades the population of adults and older adults has increased. This increase means that institutions begin to focus resources on promoting the quality of life of this group ([13], [6], [7], [10], [11]). Among the measures taken is the increase in the educational offer for this group in the formal and socio-cultural spheres. The trainer profile of adults in the formal field is represented by the Primary school teacher, for being a generalist professional (can teach diverse subjects). On the other hand, the profile of adult educators in the socio-cultural area is represented by the Social Educator. We consider that from the formation of educators for adults, it should be prepared understanding the characteristics of the collective and overcoming the stereotypes towards them. However, we find that in future educators there are stereotypes that we must face.

Continuing to be educated continually implies maturing as a citizen throughout the life cycle. Likewise, it implies assuming rights and obligations that allow the person to be an active part of society ([2], [10]). For this reason since the mid-twentieth century has been

\footnotetext{
${ }^{\text {a }}$ Corresponding author: author@e-mail.org
} 
recognized and strengthened Life Long Learning (LLL). Proof of this are the World Conferences held by UNESCO (Elsinor in 1949, Montreal in 1960, Tokyo in 1972, Paris in 1985 and Hamburg in 1997), as well as the actions of the Council of Europe, OECD, ILO or UN ([4], [12], [14], [15]). These international meetings have been crucial for the development of lifelong education.

[14] emphasize that the dimensions of these encounters are: 1) Basic or academic training; 2) Technical and vocational training; 3) Personal and cultural training; and 4) Social formation and citizen participation.

[3] indicate that adult education is conceived at all stages of education, including basic education and non-formal education, which we refer to here as "socio-cultural".

However, we prefer the definition of adult education that makes [16], "all formative action that tends to provide knowledge and skills to the people of post-school age, as well as to promote in them valuable attitudes and behaviours aimed at fostering their personal and professional development, and social participation" (p. 44).

However, this definition takes on a broader aspect with the words of [8] on lifelong education:

[...] recognizes the foundation of adult education that goes beyond compensatory education, since it raises the question that the individual must remain active throughout his or her life, which has implications for the education system and for policies developed by institutions (p. 114).

Among the principles of lifelong education, we find that it is a continuous, comprehensive, global, democratic, dynamic and flexible process, among many other issues [12]. On the other hand, [16] emphasize the lifelong character, unity, globality and universality of Lifelong Education.

\section{Method}

Among the professional exits of the Primary Education teacher and the Social Education professional, is the adult educator profile. Therefore, the objective of the research is to approximate the stereotypes that primary school teachers and early childhood educators have about adult education. To this end, 261 questionnaires have been collected (110 students of teaching in the specialty of Primary Education and 151 of Social Education) Likert type which contains eight items related to stereotypes towards adult education. It is a descriptive, quantitative, transverse and non-probabilistic study ([1], [5]).

\section{Results}

It is noteworthy that the management of ICT and the reduction of learning capacity are the stereotypes that are represented more strongly in the data obtained. Thus, we can affirm that $75 \%$ of the respondents disagree with the statement "People over 65 do not have the ability to start studying at these ages". However, $21 \%$ agree, and $4 \%$ fully agree. That is, $25 \%$ of the respondents consider that some people over 65 are not trained to study, the predominant factor being the fact of age. It is striking that a quarter of the educators in formation have this stereotype, being this group that will have to attend at some point in their professional life, especially in the field of social education (graphic 1). 
People over 65 do not have the capacity to start studying at these ages

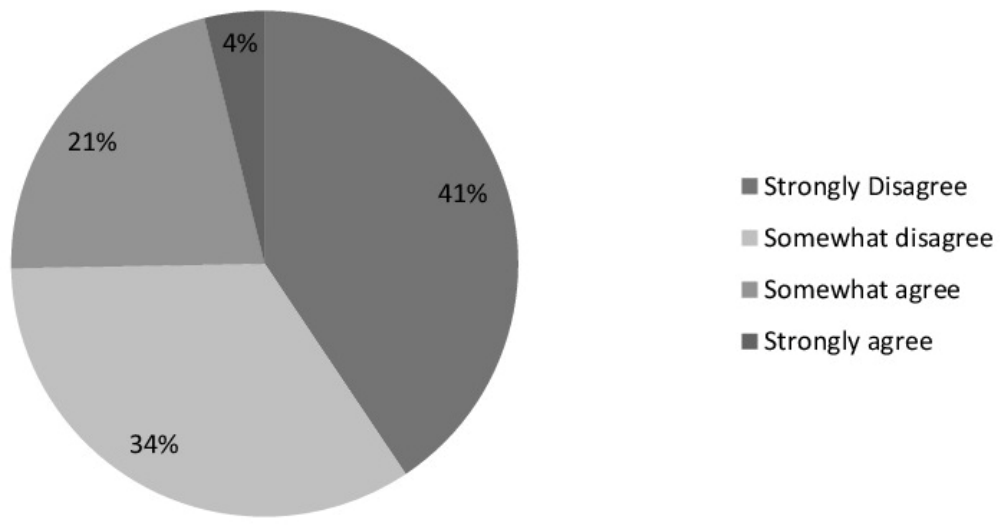

Graphic 1. People over 65 do not have the capacity to start studying at these ages.

As for the perception that the future professionals of the education have on the possibility that certain ages are learned new things, $95 \%$ of the respondents indicated that they did not agree with the statement "it's almost impossible for older people to learn new things". However, 5\% consider that at certain ages acquiring new learning is almost impossible (graphic 2).

\section{It is almost impossible for older people to learn new things}

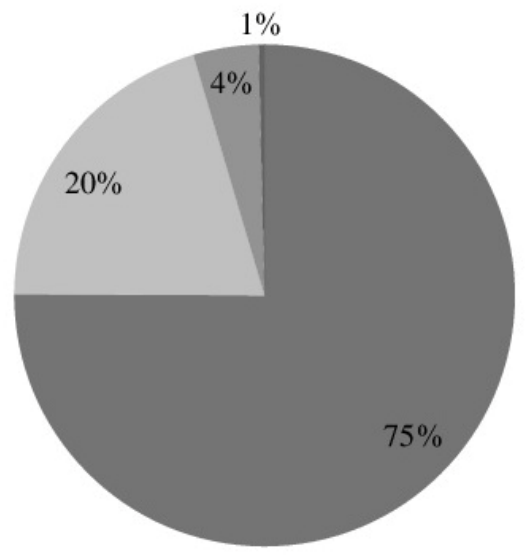

- Strongly Disagree

= Somewhat disagree

- Somewhat agree

- Strongly agree

Graphic 2. It is almost impossible for older people to learn new things

As for the use of new technologies, it is noteworthy that only $5 \%$ consider that the elderly have no problems with ICT, along with $28 \%$ who indicate that they are somewhat at odds with the statement "older people have problems using new technologies". On the other hand, $51 \%$ of educators in training point out that they are somewhat in agreement that older people have problems with ICT. $15 \%$ of respondents consider older people to have problems with ICT. We can say that in relation to the use of ICT, $66 \%$ of educators in training show stereotypes (graphic 3). 


\section{Older people have problems with ICT}

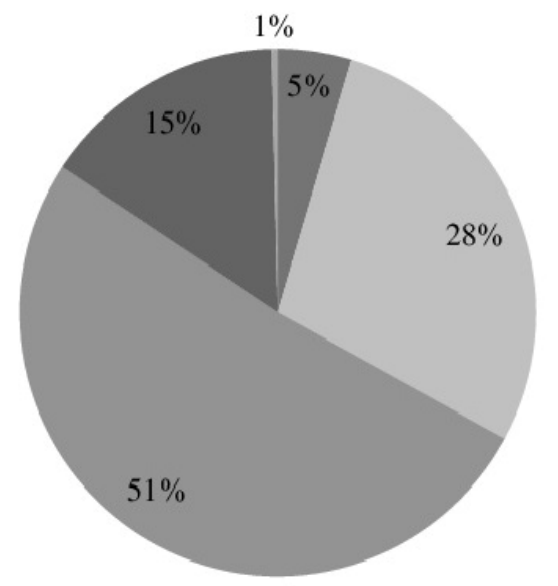

- Strongly Disagree

Somewhat disagree

- Somewhat agree

- Strongly agree

No answer

Graphic 3. Older people have problems with ICT

It draws attention to only $8 \%$ believe that learning ability does not decrease with age, along with $24 \%$ who indicate they are somewhat at odds with the statement. A total of $32 \%$ is against the claim. However, $45 \%$ are in agreement and $23 \%$ totally agree. This means that $78 \%$ of respondents show stereotypes regarding learning abilities and age (graphic 4).

\section{The learning capacity of the elderly is lower than in the young}

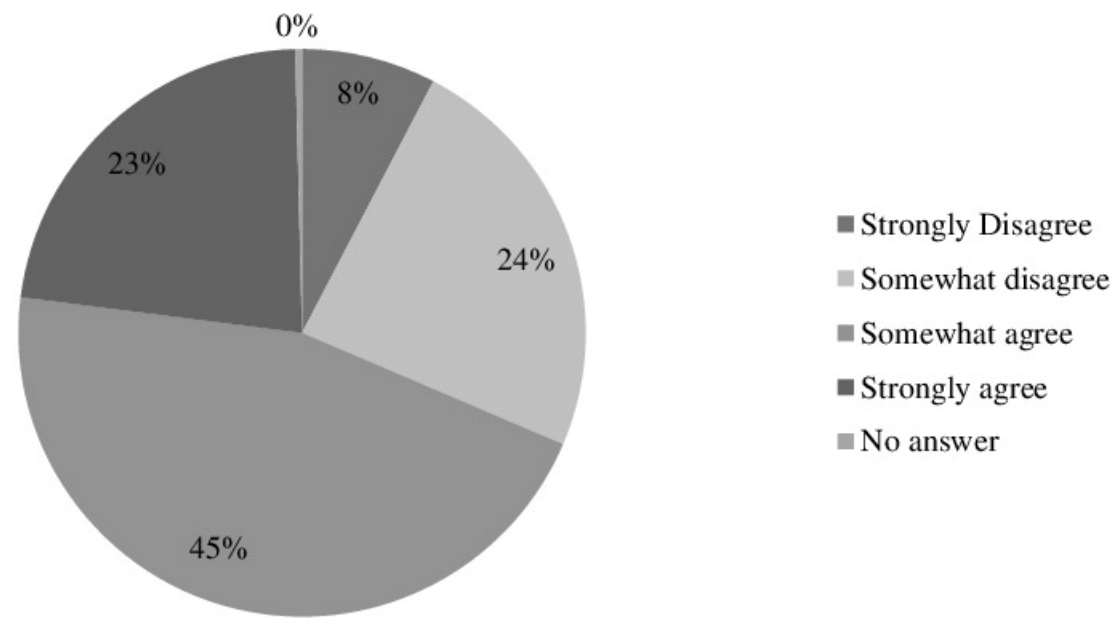

Graphic 4. The learning capacity of the elderly is lower than in the Young.

As for the statement, "as an educator I can work easily with the group of older adults", $15 \%$ of respondents consider that as educators will not work easily with older adults. Faced with 31\% who are somewhat in agreement and 54\% who totally agree (graphic 5). 
As an educator I can work easily with the group of older adults

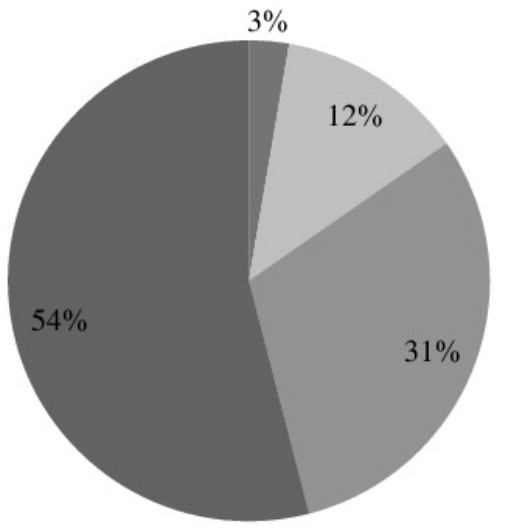

- Strongly Disagree

- Somewhat disagree

घ Somewhat agree

- Strongly agree

Graphic 5. As an educator I can work easily with the group of older adults

If we refer to the report, $50 \%$ indicate that they disagree with the statement referring to "the majority of people when they reach the age of 65 begin to have considerable memory impairment", although there is $42 \%$ who are somewhat in agreement, and $7 \%$ who fully agree. Only $1 \%$ chose not to answer the question raised (graphic 6).

\section{Most people when they reach age 65 begin to have considerable memory impairment}

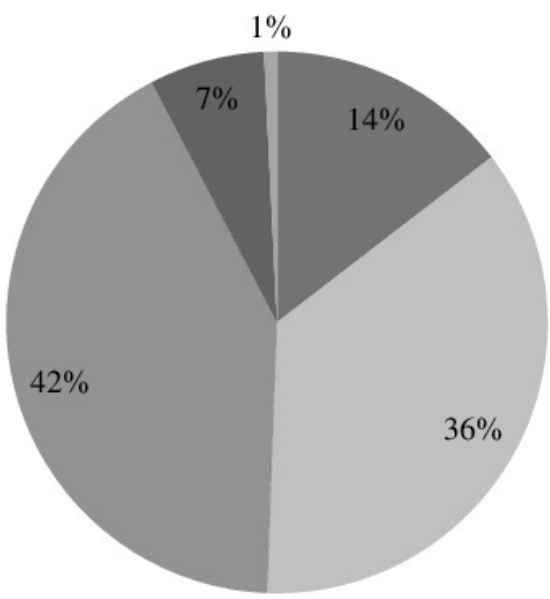

n Strongly Disagree

nomewhat disagree

- Somewhat agree

- Strongly agree

no answer

Graphic 6. Most people when they reach age 65 begin to have considerable memory impairment.

And, as we grow older we lose interest in things, or at least $54 \%$ of respondents agree with this statement, which we consider in a significant percentage taking into account the group with which we are working in this research (graphic 7). 


\section{As we get older we lose interest in things}

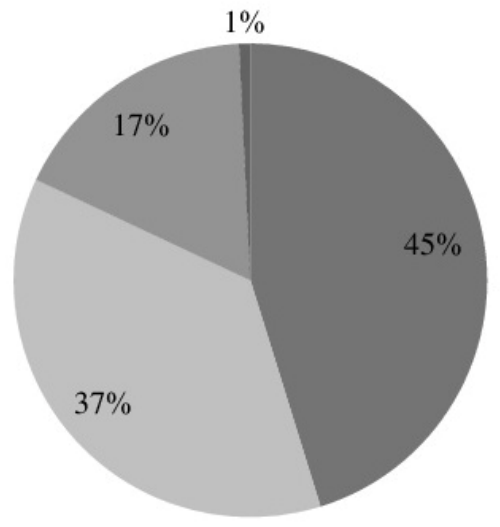

= Strongly Disagree

Somewhat disagree

Somewhat agree

- Strongly agree

Graphic 7. As we get older we lose interest in things.

As for the last question, the statement "as we age we lose the ability to solve problems," we find that $80 \%$ disagree, compared to $20 \%$ who agree with the statement (graphic 8 ).

As we grow older we lose the ability to solve problems

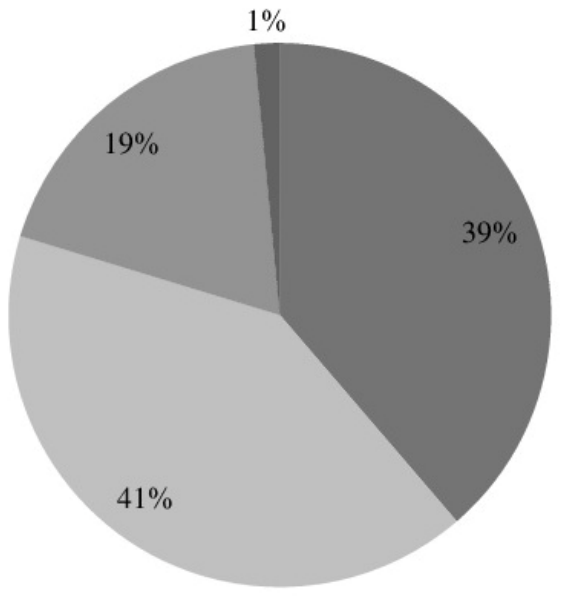

- Strongly Disagree

= Somewhat disagree

- Somewhat agree

- Strongly agree

Graphic 8. As we grow older we lose the ability to solve problems.

\section{Conclusion}

Educators in training have a series of stereotypes that the institution must face in order for future educators to have the skills needed to deal with a group with its own characteristics. The great learning that must prevail is that the education professional should approach any group without prejudice, adapting any curricular content to the needs and expectations of the group with which it will work. From the University it is imperative that there are subjects of each degree where adults can freely participate, providing the perspective and experience necessary for future educators to break the stereotypes towards the collective. 
Similarly, University Programs for the Elderly, as well as Adult Education Centers, should support the collaboration of future educators for the same purpose.

\section{References}

1. M. Canales, Metodologías de la investigación social. Santiago: LOM Ediciones. Córdoba, (2006).

2. M M $^{\mathrm{a}}$ R., Cruz Díaz, P. Moreno-Crespo, T. Rebolledo, El alumnado universitario mayor ante los recursos tecnológicos y los medios de comunicación social: El caso del Aula Abierta de Mayores, en I Simposium Internacional sobre envejecimiento activo y solidaridad intergeneracional. Madrid: UNED, 1-14 (2012)

3. J. M. Fernández-Batanero, M. M. Reyes-Rebollo, Competencias emprendedoras del alumnado de educación permanente de Andalucía. Percepción del profesorado. Educación XX1, 20(1), 253-275 (2017)

4. C. Guerrero-Romera, Principales aportaciones de las conferencias internacionales de educación de adultos de la UNESCO al campo de la formación ocupacional. Educatio, 20-21, 185-212 (2003)

5. R. Hernández, C. Fernández, P. Baptista, Metodologías de la Investigación, (2006)

6. Moreno-Crespo, P. Mayores y formación: Aprendizaje y calidad de vida. En J.C. Gómez (Coord.), I Congreso Científico de Investigadores en Formación (281-283). Córdoba: Universidad de Córdoba, (2010)

7. P. Moreno-Crespo, Mayores y Formación. Aprendizaje y Calidad de Vida. Tesis Doctoral (no publicada). Sevilla: Universidad Pablo de Olavide, (2011)

8. Moreno-Crespo, P. Educación a lo largo de la vida: aula de mayores. Revista Fuentes, 17, 113-133 (2015)

9. G. Pérez-Serrano, Aprender a lo largo de la vida. Desafío de la sociedad actual. Ágora Digital, 1, 1-17 (2001)

10. P. Moreno-Crespo, M. R. Cruz Díaz, Promoción de la calidad de vida a través de los programas socioeducativos para mayores: Universidad y mayores. En D. Cobos; A. Jaén, E. López, A.H. Martín y L. Molina (Coords.), I Congreso Virtual Internacional sobre Innovación Pedagógica y Praxis Educativa INNOVAGOGÍA. Sevilla: AFOE, (2012)

11. P. Moreno-Crespo, E. Prieto Jiménez, L. Amador Muñoz, La necesidad de proyectos socioeducativos para mayores: el caso del aula abierta de mayores. Universidad Abierta: Revista de Estudios Superiores a Distancia, 29, 141-152 (2009)

12. G. Pérez Serrano, Aprender a lo largo de la vida. Desafío de la sociedad actual. En Ágora digital, 1, 1-17 (2001)

13. E. Prieto-Jiménez, P. Moreno-Crespo, Diseñando programas para nuestros mayores: el caso del Aula Abierta de Mayores. En G. Pérez Serrano, J. García Gutiérrez y A. De Juanas Oliva (Eds.), V Jornadas de Calidad de Vida en Personas Mayores. Envejecimiento Activo y Participativo. Madrid: UNED, (2009)

14. M $\mathrm{M}^{\mathrm{a}}$ F. Ríos-González, El contenido de la Educación Permanente en las conferencias mundiales de la UNESCO. Pedagogía Social. Revista Interuniversitaria, 10, 281-297, (2003).

15. C. Sabán-Vera, Educación Permanente y Aprendizaje Permanente: dos modelos teóricos-aplicativos diferentes. Revista Iberoamericana de Educación, 52, 203-230, (2010).

16. M.L. Sarrate, M.V. Pérez, Educación de Personas Adultas. Situación actual y propuestas de futuro. Revista de Educación, 336, 41-57, (2005). 